\title{
THE REVOLT OF THE GENERAL KASSIANOS IN MESOTHYNIA (1306)
}

\author{
SaVvas Kyriakidis \\ University of Johannesburg, South Africa
}

\begin{abstract}
The first decade of the fourteenth century was a period of political, military and financial crisis in Byzantium. The inability of the government of Andronikos II Palaiologos (1282-1328) to resist the expansion of the Turcoman principalities caused the dissatisfaction of the Anatolian soldiers and resulted in a series of revolts and conspiracies. One of these was the revolt of Kassianos in Mesothynia in 1306. The analysis of this local rebellion contributes to the better understanding of the military developments in Asia Minor in the first decade of the fourteenth century.
\end{abstract}

Keywords: Kassianos - Asia Minor - Byzantine Army - Andronikos II Mesothynia.

\section{LA REVUELTA DEL GENERAL CASIANO EN MESOTINIA (1306)}

Resumen: La primera década del siglo XIV fue un período de crisis política, militar y financiera en Bizancio. La incapacidad del gobierno de Andrónico II Paleólogo (1282-1228) de resistir la expansión de los principados turcomanos causó la insatisfacción de los soldados anatolios y tuvo como consecuencia una serie de revueltas y conspiraciones. Una de ellas fue la revuelta de Casiano en Mesopotamia en 1306. El análisis de esta rebelión local contribuye a una mejor comprensión de los desarrollos militares en Asia Menor en la primera década del siglo XIV.

Palabras clave: Casiano - Asia Menor - Ejército bizantino - Andrónico II Mesotinia.

Recibido: 13.12.13 - Aceptado: 20.03.14

\section{Correspondencia: Savvas Kyriakidis.}

Email: Savkyr76@yahoo.gr Tel.0027794103085. Department of Greek and Latin Studies

Faculty of Humanities. Auckland Park Campus-Kingsway.

University of Johannesburg 2092 Johannesburg South Africa. 
The long reign of Andronikos II Palaiologos (1282-1328) is commonly seen and described by modern scholars as a period of political and economic crisis ${ }^{1}$. It was during Andronikos II's reign that Byzantium suffered substantial territorial losses, most of Asia Minor was lost to the Turks and the empire experienced a severe political crisis in the first decade of the fourteenth century. The work of George Pachymeres, whose History is the main source for the reign of Andronikos II up to 1307, and numismatic evidence suggest that in the 1290s the economic affairs of the empire deteriorated dramatically and in the 1300 s the state was effectively bankrupt ${ }^{2}$. A consequence of this profound political, military and financial crisis was the dissatisfaction of the army and its leaders which resulted in a series of conspiracies and rebellions. One of these was the revolt of the general Kassianos in Mesothynia in 1306 which is known to us through the account of Pachymeres ${ }^{3}$.

Discussing the military and political developments in Asia Minor in the first decade of the fourteenth century, Pachymeres comments that in 1306, Andronikos II sent his in-law (gamvros), Kassianos to Mesothynia to take charge of the situation there. He adds that,

"Kassianos had already been for some time in the fortresses of the area, when the council around the emperor decided to collect the usual taxes from the properties to pay the salaries of the army stationed there. Kassianos, either leading the people in a manner of a demagogue, or because of some other thought, seized Bardales, who had been sent there to collect the taxes and inflicted many wounds on him".

${ }^{1}$ The most detailed account of the reign of Andronikos II is Laiou, A. (1972). Constantinople and the Latins: The Foreign Policy of Andronikos, 1282-1328. Cambridge. MA: Harvard University Press.

${ }^{2}$ See Smyrlis, K. (2013). "Financial crisis and the limits of taxation under Andronikos II Palaiologos (1282-1321)", in eds. Angelov, D.- Saxby, M. (2013) Power and Subversion in Byzantium, Farnham: Ashgate, 72.

3 The precise location of Mesothynia has not been determined with certainty. It is part of Bithynia and it seems that it can be identified with the region north of Nicaea. See Geanakoplos, D. (1959) Emperor Michael Palaiologos and the West. A Study in Byzantine-Latin Relations. 12581282. Harvard: Harvard University Press, 27 n 44. 
Pachymeres remarks that when Bardales returned to Constantinople,

"Having accepted the words of somebody else, he reported the worst against him (Kassianos); that he had decided to form a marriage alliance with the Persian (Turk) and make a common cause with him against the interests of the empire. For that reason he was ordered to present and defend himself before the emperor. However, being despaired, Kassianos postponed his trip to the emperor. And having gained the support of soldiers, he sent to the emperor requesting assurances for his safety from the part of the emperor and advanced without being harassed. When he established himself in Chele, Kassianos believed that he had received the guarantees for his safety. Some of the inhabitants of Chele, who happened to be in the city, made an agreement with the emperor to seize the fugitive by trickery and hand him over to those who were to lead him to the emperor".

Eventually, together with an unidentified eunuch these locals seized Kassianos and sent him to the emperor in chains. Pachymeres concludes his account of the incident stating that the emperor, "Put him into prison together with Kotanitzes, because it was proven that he had written a letter to his sympetheros, the epi tou kanikleiou (Nikephoros Choumnos), in which he threatened to organize a rebellion similar to that of Kotanitzes if he was not pardoned by the emperor. And it seemed then that the emperor lost the best of his generals" ${ }^{4}$.

Rather little is known about Kassianos' career ${ }^{5}$. Pachymeres calls him an inlaw of the emperor. However, he is not known to have been married to any legitimate daughter of Andronikos II. Probably, he was married to one of his nieces or illegitimate daughters. Kassianos was also an in-law, (sympetheros), of

${ }^{4}$ Pachymeres George, GerogesPachymérès. Relations historiques, ed. Failler, A. (1984-2000) 5 vols. Paris: Institut Français d'Études Byzantines, IV, 681. Kotanitzes Tornikios was a Byzantine renegade who had joined the Serbians. He participated in a Serbian attack against Macedonia in 1280 . He was captured by the Byzantines but in 1283 he escaped and joined the Serbian ruler Stefan Uroš Milutin (1282-1321). He led Serbian attacks on the Byzantine frontier. The Serbians handed him over to the Byzantines as part of a peace agreement. Pachymeres, III, 599, IV, 298-301; Nikephoros Gregoras, Nicephori Graegorae Byzantina Historia, ed. Schopen L.- Bekker, I. (1829-1855). 3 vols. Bonn: Corpus Scriptorum Historiae Byzantinae, I, 202203; Trapp, E. (1976-1996). Prosopographisches Lexikon der Palaiologenzeit, Vienna: Verlag der Österreichischen Akademie der Wissenschaften, nr. 13317.

${ }_{5}^{5}$ Prosopographisches Lexikon, nr.11346. 
the close associate of Andronikos II, Nikephoros Choumnos ${ }^{6}$. Kassianos' status as a member of the extended imperial family must have been an important criterion for his appointed as a governor of an important province which was threatened by the raids of the Turks. He also held the office of megas primmikerios the holders of which were predominantly military men ${ }^{7}$.

Kassianos appears for the first time in the Histories of Pachymeres during the conflict between the Byzantine state and the Catalan Grand Company of mercenaries. As a consequence of the disagreements, misunderstandings and conflict with the government of Andronikos II, the Catalans abandoned Asia Minor and in 1305 moved to Europe and established themselves in Gallipoli ${ }^{8}$. Meanwhile, Kassianos was one of the generals of the army of the co-emperor Michael IX Palaiologos (1294-1320) in Adrianople. More specifically, Kassianos together with the megas hetaireiarches Nostogos Doukas were in charge of the native Byzantine soldiers of the army. It cannot be excluded that Kassianos was one of the commanders of the army Michael IX had led against the Turks in Magnesia in $1302^{9}$. Following the failure of this campaign, Michael IX withdrew to Thrace and established his court in Adrianople. Pachymeres adds that Kassianos and Nostogos Doukas were also put in charge of the fortresses that the emperor had ordered to be evacuated by their inhabitants due to the inroads of the Catalans ${ }^{10}$. Shortly after the killing of the leader of the Catalan Grand Company, Roger de Flor in Adrianople, Michael IX sent a force under Kassianos to besiege Gallipoli. According to Pachymeres, Kassianos was defeated due to the inefficiency of his troops ${ }^{11}$. Kassianos was one of the generals in the battle of Apros (20 June 1305) where the Catalans crushed the Byzantines who were led by Michael IX. Pachymeres remarks that Kassianos was in charge of the Macedonian troops ${ }^{12}$. There is no information about Kassianos' activities in the period between the battle of Apros and his appointment in Mesothynia.

${ }^{6}$ For Choumos see Prosopographisches Lexikon, nr. 30961; Verpeaux, J. (1959). Nicéphore Choumnos. Homme d'état et humaniste Byzantin (ca.1250/1255-1327). Paris: A. et J. Picard.

7 See Guilland, R. (1967). Recherches sur les institutions Byzantines, 2 vols. Amsterdam: Hakkert, I, 312-332.

${ }^{8}$ For an analysis of the Catalan campaign and the conflict between the Catalans and the empire see Laiou, Constantinople and the Latins, 131-232.

${ }^{9}$ Pachymeres, IV, 343-349; Gregoras, I, 205. For Michael IX's campaign see Laiou, Constantinople and the Latins, 90-91.

${ }^{10}$ Pachymeres, IV, 573.

${ }^{11}$ Pachymeres, IV, 577; Ramon Muntaner, Crònica, (1999). ed. Escartí, V.J. 2 vols. Valencia: Institució Alfons el Magnànim, II, 448-450.

12 These Macedonians were most likely native Byzantines from what is today's Thrace. Pachymeres, IV, 599-601; Gregoras, I, 227-232; Muntaner, 458-460. 
Pachymeres relates that Andronikos II sent Kassianos to Mesothynia at a time when he was facing difficulties on every front. Indeed, after crushing Michael IX's army in Apros, the Catalans began to ravage Thrace without the Byzantines being able to recruit a field army to face them on the battlefield. In fact, the public treasure experienced such a shortage of funds that even before the battle of Apros, in 1304, Michael IX had most of the silver and gold wares of his personal property minted into coins in order to raise an army ${ }^{13}$. The situation in Bithynia was not better. Since the last decades of the thirteenth century the Turks had been raiding and plundering the countryside of the important cities of Nicaea, Nikomedia and Prusa. The situation deteriorated after the battle of Bapheus near Nikomedia (27 July 1302) where the Ottomans under Osman defeated the Byzantines who were led by Leo Mouzalon. Pachymeres reports that Osman's successes attracted more Turcoman warriors on his side who helped him expand his possessions and influence at the expense of the Byzantines ${ }^{14}$. It is in these unfavourable political and military circumstances that Kassianos was sent to govern Mesothynia. Pachymeres does not provide details regarding his authority. Nonetheless, it seems safe to conclude that, like all provincial governors of the period, Kassianos was in charge of both the military and civil affairs of the province he was assigned to govern ${ }^{15}$.

Pachymeres begins his account of Kassianos' revolt stating that when the council around the emperor decided to collect the usual taxes from the properties in order to pay the salaries of the army, Kassianos had the tax collector, the orphanotrophos Leo Bardales, seized and beaten ${ }^{16}$. The statement that the imperial council took the decision to impose taxes reflects the style of government of Andronikos II. Pachymeres gives the impression that under Andronikos II the council around the emperor, which was composed of high-ranking officials, was not merely an advisory body. It could take decisions in important matters. For instance, Pchymeres relates that the council decided to the funding of a military

\footnotetext{
${ }^{13}$ Pachymeres, IV, 491.

${ }^{14}$ Pachymeres, IV, 365-369. For the battle of Bapheus see Inalcik, H. (1993). “Osman's Ghazi's siege of Nicaea and the battle of Bapheus", in ed. Zachariadou, E. (1993) The Ottoman Emirate. 1300-1389. Rethymnon: Crete University Press, 77-99; Kravari, V. "Évocations médiévales", in eds. Geyer, B.- Lefort, J. (2003). La Bithynie au Moyen Âge. Paris: Lethielleux, 92-96.

${ }^{15}$ Pachymeres (IV, 681) states that Kassianos was sent to arrange the affairs of Mesothynia. For the military authority of the provincial governors in the fourteenth century see Maksimovic, L. (1988). The Byzantine Provincial Administration under the Palaiologoi. Amsterdam: Hakkert, 147-148.

${ }^{16}$ For Bardales see Prosopographisches Lexikon, nr.2183.
} 
campaign on Thessaly in 1283 and it was the council's suggestion to reduce the military fleet in $1285^{17}$.

The customary taxes on land property Bardales was sent to collect must have been taxes levied on holders of imperial grants of fiscal revenues. Pachymeres indicates that it was not uncommon for the government of Andronikos II to impose such taxes. He reports that in 1283 Andronikos had planned the campaign of Michael Tarchaneiotes in Thessaly to be funded through the imperial treasury. Eventually, he accepted the proposal of the imperial council and the funds for this military operation were collected through the imposition of a new tax. This was a $10 \%$ levy "on the pronoiai of those having pronoiai," as Pachymeres remarks. He adds that, while this was collected ostensibly from the owners of the grants, the paroikoi paid everything. This implies that the holders of imperial privileges could pass the fiscal demands of the state to their depended peasants ${ }^{18}$. In 1295, Andronikos II settled Cretan mercenary soldiers in Anatolia. Pachymeres, relates that due to the lack of money the government imposed again a $10 \%$ levy on imperial grants. He identifies this tax with the one imposed in 1284. As he writes, "this was, as said earlier the tenth of the pronoia of each." Pachymeres concludes that because the possessors of these grants were deprived of money the burden was again on the paroikoi. Being critical of the fiscal policies of Andronikos II, Pachymeres comments that this caused great distress to the paroiko $i$ who were so desperate that they did not know what suffering will inflict them ${ }^{19}$. Moreover, describing the measures Andronikos II took in order to afford the salaries of the Catalan Grand Company in 1304, Pachymeres relates that the emperor appropriated one third of the pronoiai of the western parts of the empire (European provinces) ${ }^{20}$. Bartusis has recently argued that this information is not confirmed by documentary evidence and therefore, Pachymeres should refer again to a tax on imperial grants which was higher than the ones imposed in

${ }^{17}$ Pachymeres, III, 81, 121; Gregoras, I, 174-175; Laiou, Constantinople and the Latins, 38-39, 74-76.

${ }^{18}$ Pachymeres, III, 81; Laiou, A. (2000). "Le débat sur les droits du fisc et les droits régaliens au début du 14e siècle", Revue des Etudes Byzantines 58, 102; idem, Constantinople and the Latins, 38-39; Bartusis, M. (2012). Land and Privilege in Byzantium. The Institution of Pronoia. Cambridge: Cambridge University Press, 433.

${ }^{19}$ Pachymeres, III, 237; Laiou, Constantinople and Latins, 117,123; Bartusis, Land and Privilege, 433. For Pachymeres' criticism of the Palaiologoi see Angelov, D. (2007). Imperial Ideology and Political thought in Byzantium. 1204-1328. Cambridge: Cambridge University Press, 260-280.

${ }^{20}$ Pachymeres, IV, 541; Laiou, "Le débat", 103; idem, Constantinople and the Latins, 141, 188; Smyrlis, "Financial Crisis", 75. 
1284 and $1295^{21}$. Therefore, it is probable that the "customary taxes from the properties" Bardales was sent to collect the tax on imperial grants which was levied for the first time in 1284. Nevertheless, it is interesting that while in 1304 the emperor taxed only the imperial fiscal privileges in the western parts of the empire, in 1306 the imperial council decided to collect taxes from Mesothynia. The lack of sources prevents us from reaching any conclusions concerning this development. It may be assumed that on the eve of the Catalan campaign it was impossible for the empire to collect taxes from Asia Minor, or that the emperor wished to raise funds for the Catalans without burdening the Anatolian provinces. Furthermore, it is obvious that the decision to impose a tax on the revenues the holders of pronoiai had received as privileges from the throne reveals the severity of the financial crisis the empire was experiencing.

Pachymeres relates that Kassianos had Bardales seized either because he wanted to act as demagogue, or due to another reason. This statement shows that Pachymeres was uncertain whether Kassianos mistreated Bardales in order to gain popularity among the army and the local population. Trying to gain the support of the local population by mistreating state officials was something that a rebel was expected to do. For instance, in 1295, in order to satisfy the anti-aristocratic sentiment of the local soldiers, Alexios Philanthropenos, whose rebellion in the area around the Maeander was far more serious and of much larger-scale than that of Kassianos, had the emperor's brother, Theodore Palaiologos arrested in Ephessos $^{22}$. Nonetheless, as has been stated above, Pachymeres remarks that Kassianos might have had other motives. One wonders whether there were any personal differences between Kassianos and Bardales. Like Kassianos, the orphanotrophos Leo Bardales was a military man. He was a friend of Maximos Planoudes and in the late 1290s was active in Asia Minor. A letter of Planoudes indicates that Bardales was in conflict with another local general, most likely John Tarchaneiotes whom Andronikos II had sent in 1298 in Anatolia to reorganize the Byzantine military forces ${ }^{23}$. It is expected that during a period

${ }^{21}$ Bartusis, Land and Privilege, 435.

${ }^{22}$ Pachymeres, III, 245. For Philanthropenos' rebellion see Laiou, Constantinople and the Latins, 8084; idem. (1978). "Some Observations on Alexios Philanthropenos and Maximos Planoudes", Byzantine and Modern Greek Studies, 4, 89-99.

${ }^{23}$ Maximos Planoudes, Maximi Moachi Planudis Epistulae, ed. A. Leone (1991). Amsterdam: Hakkert, 11-12; Pachymeres, III, 285-289; Laiou, Constantinople and the Latins, 20-23, 34-36; For the career of Leo Bardales see Sevcenko, I. (1949). "Léon Bardales et les juges géneraux, ou la corruption des incorruptible", Byzantion, 19, 247-259. 
of crisis, territorial reduction and military failures there would be antagonism among military leaders. However, the lack of sources prevents us from reaching any conclusions regarding possible conflicts between Bardales and Kassianos.

Unsurprisingly, when Bardales returned to Constantinople, reported his mistreatment to the emperor. Pachymeres implies that the most serious accusation made by Bardales against Kassianos was that the latter was planning a marriage alliance with the Turk. It is certain that this Turk was Osman, who was the Turkish chieftain active in Bithynia. Pachymeres does not seem convinced that Kassianos had planned to form an alliance with the Turks. As he remarks, "Bardales accepted the words of someone else." Consequently, Bardales' statement against Kassianos could have been a slanderous accusation. Nonetheless, it seems that Kassianos was convinced that the emperor would accept Bardales' accusations. To avoid certain conviction, Kassianos decided not to present himself to the emperor and together with an unknown number of soldiers he occupied the fortress of Chele (modern Şile) and demanded assurances for his safety in order to travel to Constantinople.

Pachymeres indicates that after moving to Chele, Kassianos sent a letter to Nikephoros Choumnos claiming that he would revolt unless he was pardoned by the emperor. Kassianos' letter to Choumnos raises the question whether he had planned his revolt when he mistreated Bardales, or he was forced to revolt because Bardales' accusations left him with no other option. Regardless of the exact nature of Kassianos' plans, the emperor had good reasons to believe that Kassianos had planned a marriage alliance with the Ottomans. He would not have been the first Byzantine governor and general to do, or to contemplate to do so. Pachymeres reports that during his campaign in 1295 in Asia Minor, Alexios Philantropenos encountered the widow of the Turcoman leader Menteşe. He comments that Philanthropenos proposed to marry her. According to Pachymeres, this was a trick to capture the Turcoman fort. Nonetheless, one wonders whether a marriage with the widow of a prominent Turcoman leader would have served Philanthropenos' plans for his revolt ${ }^{24}$. In 1299, the daughter of the Byzantine governor of "Aydos" was married to Osman's son and successor, Orhan (1326-1362) ${ }^{25}$.

${ }^{24}$ Pachymeres, III, 239.

25 Âşık Paşazade. Osmanoĝulları' nın tarihi, eds. Yavuz, K.- Yekta Saraç, M.A.(2003). Istanbul: Koç Kültür Sanat Tandim, \$26; Bryer, A. (1981). "Greek Historians on the Turks: the Case 
Moreover, Kassianos refused to present himself to Constantinople because he could recall the fate of other prominent military leaders in Asia Minor who had been accused of treason under Andronikos II. These were more prominent and closer to the throne generals than Kassianos. In 1292, the emperor's younger brother Constantine Palaiologos and the protostrator Michael Strategopoulos were accused of plotting to seize the throne and were arrested. The pretext for Constantine's fall into disgrace was his reaction to an incident involving his wife's order of precedence in a ceremony during the festivities of the Apostles Peter and Paul $^{26}$. However, soon Constantine was accused of plotting against the emperor. As is the case with Kassianos' revolt, Pachymeres gives the impression that Andronikos II accepted the accusations various men made against Constantine without carrying out a thorough investigation ${ }^{27}$. It was said that Constantine was Michael VIII's favourite son. He possessed enormous wealth and was accused of using it to create his personal base of loyal supporters. Pachymeres remarks that the accusations against Constantine "appeared plausible to those who heard them" 28 . In March 1294, an assembly of magnates and clergymen who were called by the emperor found Constantine and Strategopoulos guilty of treason. They were not released from prison until their death ${ }^{29}$. It is interesting that while Pachymeres keeps a relatively neutral stance towards Constantine, Gregoras fully accepts his innocence ${ }^{30}$. In 1295, Alexios Philanthropenos was captured by the Cretan mercenaries who had initially incited him to revolt. Eventually, he was handed over to the governor of the theme of Neokastra, Libadarios, who had him blinded ${ }^{31}$. In 1304, the emperor's brother-in-law, Michael Angelos, who had joined Michael IX in Asia Minor in 1302, was accused of creating a private retinue composed of disposed soldiers from Asia Minor from whom he secretly demanded an oath of allegiance ${ }^{32}$. Moreover in 1305, a serious plot to overthrow

of the First Byzantine-Ottoman marriage", eds. in Davis, R.H.C. - Wallace-Hardill, J.H.M. The Writing of History in the Middle Ages. Essays Presented to Richard William Southern. Oxford: Clarendon Press, 471-493; Hopwood, K. (1999). "The Byzantine-Turkish Frontier, ca. 12501300”, in eds. Kohbach, M.-Procházka-Eisl, G.- Römer, C Acta Viennensia Ottomanica. Vienna: Selbstverlag des Instituts fur Orientalistik, 159.

${ }^{26}$ Pachymeres, I, 173; Failler, A. (1990). "Chronologie et composition dans l' Histoire de George Pachymérès (livres VII-XII)”, Revue des Études Byzantines, 48, 17-20.

${ }^{27}$ Pachymeres, III, 177-179.

${ }^{28}$ Pachymeres, III, 179.

${ }^{29}$ Pachymeres, III, 181-183.

${ }^{30}$ Gregoras, I, 186-191.

${ }^{31}$ Pachyemeres, III, 251-253.

${ }^{32}$ Pachymeres, III, 435-37. 
the emperor, which involved military officers and refugees from Asia Minor, was averted and its leaders were imprisoned ${ }^{33}$.

Kassianos was supported by an unknown number of soldiers who followed him to the fortress of Chele. To understand the motives of Kassianos' followers it is necessary to summarize the position of the Byzantine soldiers in the last decades of the thirteenth century, as it is described by Pachymeres. In the preface of his work Pachymeres describes how the Laskarid rulers of the so-called empire of Nicaea reinforced the defence of its eastern frontier by providing incentives (pronoia grants, tax exemptions, cash) to local troops to remain to their lands and defend them against the raids of Turcoman chiefdoms which were not under the control of the Seljuk sultanate of Rum ${ }^{34}$. A few months after the recovery of Constantinople, in December 1261, Michael VIII faced a popular revolt in Zegynoi, in the frontier region south east of Nicaea ${ }^{35}$. In the wake of this revolt Michael VIII sent Constantine Chadenos to Anatolia to reform the remuneration of the Anatolian troops ${ }^{36}$. Scholars have expressed different views regarding the nature of Chadenos' reforms. Others claimed that Chadenos reduced the holdings of the wealthy frontier guards and others concluded that he conducted a reassessment of the pronoiai of these troops ${ }^{37}$. Most recently, Bartusis has shown that Chadenos turned these frontier guards into mercenaries ${ }^{38}$. Pachymeres implies that a consequence of Chadenos' reforms was the decline of the system of the frontier guards. He remarks that the payments that have been assigned to the soldiers in the frontier were discontinued, since those in charge were stingy and the leaders of the army kept most of the share of the soldiers in the manner of thieves. As a result, as Pachymeres continues, many soldiers were either lost, or joined the enemy while others became brigands and terrorized the local population $^{39}$. Pachymeres' conclusion seems to be confirmed by Gregoras who

${ }^{33}$ Pachymeres, IV, 653; Failler, A. (1996). "Le complot antidynastique de Jean Drimys", Revue des Études Byzantines, 54, 235-244.

${ }^{34}$ Pachymeres, I, 29-31. For the frontier guards see Oikonomides, N. (1981). "À propos des armées des premières Paléologues et les compagnies de soldats", Travaux et Mémoires, 8, 359; Bartusis. M. (1990). "On the Problem of Smallholding Soldiers in Late Byzantium", Dumbarton Oaks Papers, 44, 2-3; idem. (1992). The Late Byzantine Army, 1204-1453. Philadelphia: Pennsylvania University Press, 25-26; idem, Land and Privilege, 226-227.

35 Pachymeres, I, 259-263.

${ }^{36}$ Pachymeres, I, 31-33. For Constantine Chadenos see Prosopographisches Lexikon, nr. 30346.

${ }^{37}$ See Bartusis, M. (2008). "The Chadenos Affair (Pachymeres, Book 1, Chapters 5-6)”, Zbornik Radova Vizantološkog Instituta, 45, 161.

${ }^{38}$ Bartusis, "The Chadenos Affair", 157-168.

${ }^{39}$ Pachymeres, I, 35. 
writing about events from the 1270s remarks that the guards of the frontier had migrated a few years earlier because their annual stipends were discontinued ${ }^{40}$. Moreover, Pachymeres comments repeatedly that the Anatolian provinces had been overtaxed by corrupt and unworthy officials ${ }^{41}$.

Consequently, the impression given by Pachymeres is that since the 1260 s the soldiers of Anatolia were deeply disaffected by the policies of Michael VIII, who seems to have mistrusted them. Being threatened by the increased raids of the Turcomans and neglected by the government, these troops became prone to revolt and supported ambitious military commanders. Most of these generals had limited or no personal ties with Asia Minor. Nonetheless, their military reputation was sufficient to lead local disgruntled soldiers to rally around them. As is the case with Kassianos, these commanders revolted either in order to promote their personal interests, or they were forced to rebellion because they were slandered or suspected by the throne. In 1280, John Doukas Angelos, who in the 1270s achieved victories against the Turks, was accused of insulting Constantine Palaiologos (Michael VIII's second son). He was arrested and blinded. Almost at the same time, the general of Herakleia on the Black Sea, Michael Srategopoulos was arrested under the accusation of plotting against the emperor ${ }^{42}$.

The attempts of Michael VIII's successor, Andronikos II to reinforce the frontier had limited effect and did not improve the fortunes of local soldiers. The rhetoric of the revolt of Alexios Philanthropenos in 1295, as reported by Pachymeres reflects the complaints of the local soldiers against the throne and the ruling elite. Pachymeres writes that many soldiers who joined the revolt believed that while they were fighting, the Constantinopolitan elite were enjoying the fruits of their struggle and leading a luxurious life, without satisfying the needs of the soldiers ${ }^{43}$. In 1298, Andronikos II sent John Tarchaneiotes in Asia Minor to re-organize the armies of Asia Minor ${ }^{44}$. Philanthropenos' revolt and the failure of the reforms of John Tarchaneiotes seem to have led Andronikos II's to the decision to employ mercenaries from outside the empire for the defence of Asia Minor. Discussing the employment of Alan mercenaries in 1301, Pachymeres criticizes Andronikos

\footnotetext{
${ }^{40}$ Gregoras, I, 138; Bartusis, “The Chadenos’ Affair”, 158.

${ }^{41}$ Pachymeres, I, 291-293, II, 405-407, 633-635, III, 235.

${ }^{42}$ Pachymeres, II, 613-617, 621-623.

${ }^{43}$ Pachymeres, III, 241.

${ }^{44}$ Pachymeres, IV, 285-289; Laiou, Constantinople and the Latins, 87-89; Oikonomides, "À propos des armées", 354; Bartusis, The Late Byzantine Army, 75-76.
} 
II for neglecting the native soldiers in favour of foreign mercenaries. Similarly, Gregoras comments that after the rebellion of Philanthropenos, Andronikos II "day and night he was dreaming of overseas alliances" 45 . In his account of the battle of Bapheus in 1302 Pachymeres implies that the employment of the Alan mercenaries had a damaging effect on the morale of the native soldiers. He writes that the Byzantine soldiers were unwilling to fight because of the money and weapons that had been taken away from them to supply the Alan mercenaries ${ }^{46}$. Describing events shortly after the battle of Bapheus, Pachymeres relates that in 1303 the government considered to reinforce the defence in Asia Minor by confiscating and distributing grants of land which had belonged to ecclesiastical institutions and wealthy individuals who had abandoned them. The government was hoping that the new holders would be motivated to fight for the source of their incomes ${ }^{47}$. This plan was never materialised and as Pachymeres relates, shortly afterwards many soldiers of the vassilika allagia, which were units of the field army stationed in Asia Minor, migrated from Asia to the west due to the inroads of the Turks ${ }^{48}$. Being disaffected and alienated by the inability of the throne to protect their interests and having suffered the economic and social consequences of the Turcoman raids and expansion, the remaining soldiers became prone to rally around rebellious generals or to support individuals of obscure origin, such as the Bulgarian John Choirovoskos, who leading a band of 300 archers and mace-bearers offered to fight against the Turks in $1304^{49}$.

Furthermore, many soldiers and local commanders in Bithynia appear to have begun to co-operate with the Turks. Pachymeres remarks that since the reign of Michael VIII Byzantine soldiers had begun to join the enemy. Nonetheless, it seems that in the first decade of the fourteenth the number of Byzantine soldiers and local commanders who joined the Turks was increased. One wonders whether it is a coincidence that the appearance of individuals such as the Christian collaborator of Osman, Köse Mihal, who is identified as the head of

${ }^{45}$ Pachymeres, IV, 339; Gregoras, I, 205; Kyriakidis, S. (2009). "The Employment of Large Groups of Mercenaries in Byzantium in the Period ca. 1290-1305 as Viewed by the Sources", Byzantion, 79, 212.

${ }^{46}$ Pachymeres, IV, 367; Kyriakidis, S. Warfare in Late Byzantium, 1204-1453, Leiden, 2011, 120-121; S. Jesee-A. Isaenko. (2013). "The Military Effectiveness of Alan Mercenaries in Byzantium. 1301-1306", Journal of Medieval Military History, 11, 107-131.

${ }^{47}$ Pachymeres, IV, 425-427; Kyriakidis, Warfare in Late Byzantium, 77. For the dating of these events see Failler, A. (1993). "Pachymeriana alia", Revue des Études Byzantines, 51, 248-258.

${ }^{48}$ Pachymeres, IV, 447.

${ }^{49}$ Pachymeres, IV, 487-489; For Choirovoskos see Prosopographisches Lexikon, nr. 30786. 
the fortress of Harmankaya in the Ottoman chronicles, coincides chronologically with Pachymeres' aforementioned remarks that in 1303 and 1304 many soldiers had lost their pronoiai. ${ }^{50}$ Consequently, it is obvious that Kassianos' followers were desperate soldiers who were experiencing the economic, social and political consequences of the collapse of imperial control over Asia Minor.

The fact that Kassianos was seized by inhabitants of Chele raises the question whether he had received any support from the local population or the aristocracy. On the one hand, that he was captured and handed over to the authorities by locals does not prove that the majority of the population of Mesothynia was hostile towards him. On the other hand, there is no evidence to suggest that apart from the soldiers who were stationed in Mesothynia any other group supported Kassianos. Moreover, Kassianos' rebellion does not seem to have received the backing of members of the higher aristocracy. Pachymeres indicates that Kassianos' letter to Nikephoros Choumnos was merely an admission that he would revolt unless he was pardoned. It does not implicate Choumnos or anyone else to the conspiracy. It also seems that none of the revolts and conspiracies in Asia Minor reflected any reaction of the aristocracy against the throne. Shortly after the recovery of Constantinople, Michael VIII faced the dissatisfaction of the Anatolian soldiers. However, it seems that his policy of expansion westwards, one of the effects of which was the negligence of the Anatolian frontier, served the interests of the aristocracy the members of which had received privileges and grants of land in the newly annexed territories in the Balkans ${ }^{51}$. In addition, it is probable that while he faced the discontent and bitterness of the Anatolian soldiers, Andronikos II protected the financial interests of the great aristocrats and monastic foundations. Privileged people and institutions suffered much less than others in the $1290 \mathrm{~s}$ and $1300 \mathrm{~s}^{52}$.

In conclusion, compared with rebellions like that of Alexios Philanthropenos and the alleged conspiracies of Constantine Palaiologos and Michael Strategopoulos, the conspiracy of Kassianos was a small-scale rebellion. Nonetheless, it reflects the political, social and military realities in Bithynia

\footnotetext{
50 Âşık Paşazade, \$9, 10, 11, 22, 23; Hopwood, K. (1992). "Low-level diplomacy between Byzantines and Ottoman Turks: the case of Bithynia", eds. in J. Shepard - S. Franklin. Byzantine Diplomacy, Aldershot: Variorum, p151-155; Lowry, H. (2003). The Nature of the Early Ottoman State. New York: State University of New York, 66-70.

51 Kyritses, D. (1999). “The 'Common Chrysobulls' of Cities”, Vyzantina Smmeikta, 13, 241.

52 See Smyrlis, "Financial Crisis", 79-80.
} 
in the first decade of the fourteenth century. In the aftermath of the battle of Bapheus, the increased Turkish raids and the fiasco of the employment of the Catalan Grand Company, the emperor sent Kassianos, a successful general who was a member of the extended imperial family to govern the important frontier province of Mesothynia. Like other leading generals before him, such as Michael Angelos, Constantine Palaiologos and Alexios Philanthropenos, Kassianos had either plans to take advantage of the declining imperial control over Anatolia and promote his personal interests by orchestrating a rebellion, or was forced to revolt because he was slandered by a rival official who had accused him of arranging a marriage alliance with Osman. Considering the gravity of this accusation and the fate of rebellious commanders before him, Kassianons decided not to present himself to the emperor. Kassianos seems to have been convinced that the emperor would find Bardales' accusations reliable. This reflects the lack of trust between the throne and the frontier commanders and their troops in Asia Minor. Like all rebellious commanders in Asia Minor before him, Kassianos was followed by disgruntled and alienated soldiers. The government in Constantinople had failed to defend their interests and protect their possessions and by the time Kassianos was appointed governor of Mesothynia many of them had already migrated to the western parts of the empire. Those who remained in Asia Minor would either begin to co-operate with the Turks or supported rebellious commanders, who like Kassianos, might had limited connections with the area but their military reputation was sufficient to attract them. 


\section{Bibliography Primary Sources}

ÂşıK Paşazade. (2003). Osmanoĝulları' nın tarihi. eds. Yavuz, K., Yekta Saraç, M.A. Istanbul: Koç Kültür Sanat Tandim.

Gregoras, Nikephoros. (1829-1855). Nicephori Graegorae Byzantina Historia, 3 vols. eds. Schopen L.- Bekker, I. Bon: Corpus Scriptorum Historiae Byzantinae.

Muntaner, R. (I 999). Crònica, 2 vols. ed. Escartí, V.J. Valencia: Institució Alfons el Magnànim.

Planoudes Maximos, Maximi Planoudis Epistulae, ed. A. Leona (1991). Amsterdam: Hakker.

Pachymeres George. (1984-2000). GerogesPachymérès. Relations historiques, 5 vols. ed. Failler, A. Paris: Institut Français d' Études Byzantines.

\section{Secondary Sources}

Angelov, D. (2007). Imperial Ideology and Political Thought in Byzantium. 1204-1328. Cambridge: Cambridge University Press.

Bartusis, M. (I990). "On the Problem of Smallholding Soldiers in Late Byzantium”, Dumabarton Oaks Papers, 44, 1-28.

Bartusis, M. (1992). The Late Byzantine Army, 1204-1453. Philadelphia: Pennsylvania University Press.

Bartusis, M. (2008). "The Chadenos Affair (Pachymeres, Book 1, Chapters 5-6)”, Zbornik Radova Vizantološkog Instituta, 45, 157-169.

Bartusis, M. (2012). Land and Privilege in Byzantium. The Institution of Pronoia. Cambridge: Cambridge University Press.

Bryer, A. (I98I). "Greek Historians on the Turks: the Case of the First Byzantine-Ottoman Marriage", in eds. Davis, R.H.C., Wallace-Hardill, J.H. The Writing of History in the Middle Ages. Essays Presented to Richard William Southern. Oxford: Clarendon Press, 471-493.

Failler, A. (I990). "Chronologie et composition dans l' Histoire de George Pachymérès (livres VII-XII)”, Revue des Études Byzantines, 48, 5-87.

Failler, A. (1993). "Pachymeriana alia”, Revue des Études Byzantines, 51, 237-260.

Failler, A. (1996). "Le complot antidynastique de Jean Drimys", Revue des Études Byzantines, 54, 235-244.

Geannakoplos, D. (1959). Emperor Michael Palaiologos and the West. A Study in Byzantine-Latin Relations. 1258-1282. Harvard: Harvard University Press. 
Guilland, R. (1967). Recherches sur les institutions Byzantines, 2 vols. Amsterdam: Hakkert.

Hopwood, K. (1992). "Low-level diplomacy between Byzantines and Ottoman Turks: the case of Bithynia", in eds. J. Shepard- S. Franklin, Byzantine Diplomacy, Aldershot: Variorum, 151-155.

Hopwood, K. (I999). “The Byzantine-Turkish Frontier, ca. 1250-1300”, in eds. Kohbach, M., Procházka-Eisl, G., Römer , C. Acta Viennensia Ottomanica. Vienna: Selbstverlag des Instituts fur Orientalistik , 153-161.

INALCIK, H. (I993). "Osman's Ghazi's siege of Nicaea and the battle of Bapheus", in ed. Zachariadou, E. The Ottoman Emirate. 1300-1389. Rethymnon: Crete University Press, 77-99.

Kravari, V. (2003). "Évocations médiévales", in eds. B. Geyer- J. Lefort, La Bithynie au Moyen Agge. Paris: Lithelleux.

Kyriakidis, S. (2009). "The Employment of Large Groups of Mercenaries in Byzantium in the Period ca. 1290-1305 as Viewed by the Sources", Byzantion, 79, 208-230.

Kyriakidis, S. (20 I I). Warfare in Late Byzantium, 1204-1453.Leiden: Brill.

Kyritsis, D. (1999). "The 'Common Chrysobulls' of Cities", Vyzantina Symmeikta, 13, 229-245.

Laiou, A. (1972). Constantinople and the Latins: The Foreign Policy of Andronikos, 1282-1328, Cambridge. MA.: Harvard University Press.

Laiou, A. (2000). "Le débat sur les droits du fisc et les droits régaliens au début du 14e siècle", Revue des Études Byzantines, 58, 97-122.

Mansimovic, L. (1988). The Byzantine Provincial Admonistration under the Palaiologoi. Amsterdam: Hakkert.

Oíonomides, N. (I 98 I). "À propos des armées des premières Paléologues et les compagnies de soldats", Travaux et Mémoires, 8, 353-371.

Sevcenko, I. (1949). "Léon Bardales et les juges géneraux, ou la corruption des incorruptible", Byzantion, 19, 247-259.

Smyrlis, K. (2013). "Financial crisis and the limits of taxation under Andronikos II Palaiologos (1282-1321)", in eds. D. Angelov - M. Saxby, Power and Subversion in Byzantium, Farnham: Ashgate, 71-83.

Trapp, E. (I976-I996). Prosopographisches Lexikon der Palaiologenzeit. Vienna: Österreichscen Akademie der Wissenschafte.

Verpeaux, J. (1959). Nicéphore Choumnos. Homme d'état et humaniste Byzantin (ca.1250/1255-1327. Paris: A. et J. Picard. 